\title{
Exploring the complexity of microfinance and HIV in fishing communities on the shores of Lake Malawi
}

Eleanor, E. MacPherson, Liverpool School of Tropical Medicine, Pembroke Place, Liverpool, UK, Malawi-Liverpool-Wellcome Trust Clinical Research Programme, PO 30096, Chichiri 3, Blantyre, Malawi

John Sadalaki, Malawi-Liverpool-Wellcome Trust Clinical Research Programme, PO 30096, Chichiri 3, Blantyre, Malawi; College of Medicine, University of Malawi, Mahatma Gandhi Campus, Blantyre, Malawi

Victoria Nyongopa, Malawi-Liverpool-Wellcome Trust Clinical Research Programme, PO 30096, Chichiri 3, Blantyre, Malawi

Lawrence Nkhwazi, Malawi-Liverpool-Wellcome Trust Clinical Research Programme, PO 30096, Chichiri 3, Blantyre, Malawi

Mackwellings Phiri, Malawi-Liverpool-Wellcome Trust Clinical Research Programme, PO 30096, Chichiri 3, Blantyre, Malawi

Alinafe Chimphonda, Malawi-Liverpool-Wellcome Trust Clinical Research Programme, PO 30096, Chichiri 3, Blantyre, Malawi

Nicola Desmond, Liverpool School of Tropical Medicine, Pembroke Place, Liverpool, UK, Malawi-Liverpool-Wellcome Trust Clinical Research Programme, PO 30096, Chichiri 3, Blantyre, Malawi

Victor Mwapasa, College of Medicine, University of Malawi, Mahatma Gandhi Campus, Blantyre, Malawi

David G. Lalloo, Liverpool School of Tropical Medicine, Pembroke Place, Liverpool, UK,

Janet Seeley, Medical Research Council/Uganda Research Unit on AIDS, Entebbe, Uganda, School of International Development, University of East Anglia, Norwich, UK Sally Theobald, Liverpool School of Tropical Medicine, Pembroke Place, Liverpool, UK

\section{Abstract}

This study utilised qualitative research methodology to explore female fish traders' experiences of accessing microfinance in fishing communities in Southern Malawi. 
Microfinance is a tool that has been used to alleviate poverty. People living in fishing communities in the Global South are at an increased risk of HIV and, equally, microfinance has been identified as a tool to prevent HIV. Our research found consistent testimonies of overly short microfinance loan repayment periods, enforced by the threat of property confiscation. These threats, coupled with gendered power-dynamics and the unpredictability of fish catches, left some female fish traders vulnerable to HIV.

Keywords: HIV, microfinance, women's empowerment, fishing communities 


\section{Introduction}

Since the 1980 s, microfinance ${ }^{1}(\mathrm{MF})$ has become the international community's most prevalent development tool to alleviate poverty in the global South.

Microfinance usually involves the offering of small loans to poor households that have been excluded from the formal banking system because they lack collateral and are therefore deemed to be too high risk to receive loans (Morduch 2000). The underlying logic of providing financial services to poor people is that this will result in improved capacity to manage money and result in greater investment, acquisition of productive assets and increased development of skills and knowledge (van Rooyen, Stewart and de Wet (2012).

Microfinance programmes are among the most well-funded development interventions and there have been ambitious claims about the far reaching impact MF can make on their loan recipients lives (Visvanthan and Yoder 2011). There is a vast academic literature dedicated to the analysis of microfinance programmes and assessment of their impact on outcomes including poverty, health and wellbeing and empowerment (Banerjee et al. 2013; Holvoet 2005; Karlan and Valdivia 2011; Korth et al. 2012; Mersland and Strøm 2010; van Rooyen, Stewart and de Wet 2012). Microfinance programmes have penetrated almost all regions of the globe, but are especially concentrated in the poorest countries of the world, particularly in South Asia and sub-Saharan Africa. Recent academic work that has systematically reviewed the impact of microfinance programmes has found very limited evidence to support

\footnotetext{
1 The term microfinance is often used as an umbrella term to a range of financial services including refer to micro-loans, microinsurance and village banking. In general the term is focused on programmes that provide credit.
} 
many of the ambitious claims made by the microfinance industry (van Rooyen, Stewart and de Wet 2012). Further, studies have demonstrated the range of negative impacts microfinance can have on loan recipients and at the broader community level (Bateman and Chang 2012).

While there is considerable diversity in the operating practices of microfinance programmes, they often have a number of common features. The first is the practice of group lending, where group members assume the responsibility for repaying the whole loan - this has also been referred to as 'joint liability' (Marr 2012). Secondly, the grace period between signing the loan agreement and first loan repayment or compulsory saving deposit is typically very short (usually within 2-4 weeks). Finally, groups may only graduate to take a subsequent, larger loan once they have successfully completed repayments on their first loan (Sengupta and Aubuchon 2008).

There has been a vast literature dedicated to this work in a number of academic fields. These include the international development, gender studies and HIV. To frame our research we discuss the academic debates about microfinance and women's empowerment; microfinance and sub-Saharan Africa and finally microfinance as a tool to prevent HIV.

\section{Microfinance, women's empowerment and HIV prevention}

Globally, the majority of microfinance recipients are women. Microfinance organisations have made ambitious claims regarding the power of microfinance to 
achieve women's empowerment and poverty alleviation (Mayoux 1999; Visvanthan and Yoder 2011), although academic researchers have often contested these claims. Claims relating to women's empowerment are built on the argument that provision of financial services to poor women (including loans and opportunities to saving) will enable women to generate or support self-employment (Johnson 2005). Further, it is anticipated that the money that women generate through this employment will enhance their role in household decision-making, as well as increasing confidence to negotiate with partners (Johnson 2005; Pankhurst 2002). The group-based nature of microfinance programmes is also seen as providing women with an opportunity to participate in a wider social network, foster engagement in political activities and provide the opportunity for social change (Kalpana 2011; Pankhurst 2002).

Despite these laudable aims, a growing body of academic work has challenged the validity of microfinance organisations' claims of success in achieving povertyalleviation and empowerment (Cornwall and Edwards 2010; Goetz and Gupta 1996; Kalpana 2011; Mayoux 1999; Pankhurst 2002; Rahman 1999). Visvanthan and Yoder (2011) suggest that microfinance organisations may promote empowerment without sufficiently emphasising either transformation of dynamics within the household, or the social and cultural structures that perpetrate inequality. Cornwall and Edwards (2010) argue that women's empowerment is a complex process that requires more than one simple intervention (Cornwall and Edwards 2010). In short, by focusing on the individual as a means of overcoming poverty, microfinance programmes fail to address the broader structural factors (both at the local as well as the international 
level) that drive poverty and gender imbalances at the household and community levels (Pankhurst 2002).

Further, a number of studies have questioned whether microfinance may actually be harmful for women. Empirical studies, mainly undertaken in South Asia, have reported disempowering outcomes for female recipients of microfinance. Goetz and Gupta (1996) found that a significant proportion of women's loans were controlled by male relatives in households in Bangladesh. The authors also argued that the preoccupation with 'credit performance', measured primarily in terms of high repayment rates, affects the incentives of fieldworkers dispensing and recovering credit in ways that may outweigh concerns to ensure that women develop meaningful control over their investment activities.

One of the central aims of microfinance organisations is to alleviate poverty in developing countries. However, Matin and Hulme (2003) show that microfinance frequently fails to reach the poorest members of the communities in which they work (Matin and Hulme 2003). This may be a policy that is actively encouraged by some MF organisations because the poorest groups may be less likely to repay their loans (ibid). Matin and Hulme (2003) also note that microfinance might not be most suitable for the poorest groups. They argue that for households who are trapped in chronic food insecurity and who lack the asset base to protect themselves from shocks to their income and food supply "microfinance can be ineffective and sometimes counterproductive" (Matin and Hulme 2003: 653). These findings are further supported by Bateman and Chang (2012) who review of the impact of 
microfinance on recipients. In their review they argue that the microfinance model can lock people and communities in a poverty trap and has had catastrophic outcomes in a growing number of microfinance-statured countries such as Bangladesh and states of India (Bateman and Chang 2012).

Rahman (1999) found that the need for timely repayment in loan centres in Bangladesh led to MF loan officers and other lending-group members placing intense pressure on female clients. Many of the borrowers maintained regular repayment through loan recycling that led to considerable increases in the debtliability of the individual households. This in turn led to an increase in tension and frustration in the household and violence against female members (Rahman 1999). Bateman and Chang (2012) presented the case of the Indian state of Andhra Pradesh where poor households in the state were on average in possession of a total of 9.3 microloans. Households took out loans to cover the repayment of earlier microloans. This led in late 2010 to what the authors describe as "Andhra Pradesh's microfinance industry effectively collapsed" (Bateman and Chang 2012: 16).

Kabeer (2001), however, challenges some of the negative findings relating to women in microfinance programmes (such as those presented in Goetz and Gupta (1996)). In her work, which used qualitative and participatory methods, she found that women's access to loans gave them the support to improve their bargaining position within the household. 
As noted earlier, much of the research exploring the impact of MF programmes on women's empowerment has been conducted in South Asia. Many feminist scholars have noted that gender power relations are context specific and there are differences in the social norms that govern women and men's behaviour in subSaharan Africa and South Asia. These different social norms are likely to have an impact on how men and women can use the loans.

In one study exploring the impact of MF in a range of African countries Mayoux (1999) argues that the impact of MF in Africa has been mixed. Mayoux (1999) used mostly unpublished secondary data analysis from microfinance programmes and her own exploratory research to understand the impact of microfinance on women's empowerment. In this study, African women were generally more widely involved in production and market activities than women in South Asia, and this meant they were more likely to retain and use their own income. The pre-existence of welldeveloped networks between women meant that microfinance did not necessarily make a considerable contribution to women's social empowerment, as was seen in South Asian programmes. Finally, Mayoux (1999) raised the criticism that microfinance programmes in Africa have been far more concerned with financial sustainability than with achieving a broader impact on women's empowerment. This also suggests that the model of microfinance was exported from South Asia to subSaharan Africa with very little involvement of local women and men and limited discussion of context. It also means that the design of these programmes could fail to reflect the reality of lives of participants receiving the loans. 
Kabeer (2005) argues that the debate over microfinance has been divided, with those who have an evangelistic zeal for promoting its use being matched by the outright rejection by its opponents. In reality, Kabeer (2005) argues that the impact of microfinance is like any development resource and "represents a range of possibilities, rather than a predetermined set of outcomes." (Kabeer 2005: 4709). Kabeer (2005) also states that the impact of microfinance is dependent on a wide range of factors including "the philosophy that governs their delivery, the extent to which they are tailored to the needs and interests of those they are intended to reach, the nature of the relationships which govern their delivery and - that most elusive of all developmental inputs - the calibre and commitment of the people who are responsible for delivery" (ibid).

In the field of HIV prevention there has been an increased focus on the potential MF programmes have to prevent HIV (Dworkin and Blankenship 2009; Kim and Watts 2005). The rationale for this argument is based on the claims that MF programmes automatically empower women. Women's economic dependence on their sexual partner has been identified as a key vulnerability to HIV. This is because women and girls who are economically dependent on their sexual partners have been found to be more likely to engage in sexually risky situations; less likely to leave abuse relationships; more likely to exchange sex for material goods and less able to negotiate safer sex (Dunkle et al. 2004a; Dunkle et al. 2004b; Dworkin and Blankenship 2009; Epstein 2007). These are all factors that have been identified to increase women and girls' vulnerability to HIV. Therefore, central to the claim that MF might be a tool that prevents HIV is that if MF provides women with an 
alternative form of income they will become less dependent on their male partners (Dworkin and Blankenship 2009). In the field of public health structural interventions (interventions that alter the broader risk environment rather than focusing on the individual behaviour change) have taken a greater prominence particularly in relation to HIV (Seeley et al. 2012). In two countries with very high HIV prevalence (South Africa and Zimbabwe) interventions that use microfinance have been trialled to identify whether microfinance could prevent HIV. The rationale being that MF can support change in the broader social environment by economically empowering women and therefore preventing HIV. The IMAGE Study, which used MF combined with gender training, was conducted in mining communities in rural South Africa, found a reduction in gender based violence but no impact on reductions in HIV transmission. A paper based on these findings was published in the Lancet (Pronyk et al. 2006). The SHAZ Study, based in Harare, was conducted with young female orphans and combined gender training with microfinance. The study took place in 2004, when Zimbabwe was facing a severe economic crisis and the provision of microfinance loans to this vulnerable group "increased participants exposure to physical harm, sexual abuse and coercion" (Dunbar et al. 2010: 158).

\section{Fishing communities, HIV vulnerability and the rationale for this study}

Fishing communities in the Global South have been identified as a group particularly vulnerable to HIV (Kissling et al. 2005; Kwena et al. 2013; Tumwesigye et al. 2012). In Malawi, fishermen have also been identified as a group with higher risk of HIV with prevalence estimates for this group standing at $16.6 \%$ (Government of Malawi 
2006; Government of Malawi 2009). This is higher than the national prevalence rate that stands at $11.7 \%$. Further, in the lakeside district of Mangochi, where there the study was situated, prevalence stands at $13.1 \%$, which is higher than other rural Malawian districts.

There are a number of factors that have been identified in the fishing industry particularly in Eastern Africa that drives this vulnerability. Fishing often requires frequent travel; both for the men who catch the fish as well as for the men and women who buy, process and sell the fish at markets (Kwena et al. 2013; Seeley, Tumwekwase and Grosskurth 2009). Travel can lead to men and women having additional sexual partners (for men this is often sex workers, whilst for women this often involves transactional sexual partnerships and receipt of some material benefit). Travel is often combined with high levels of alcohol consumption, which can lead to risky sex (Tumwesigye et al. 2012). Although, it is important to note that not all travel leads to higher HIV risk (Deane, Parkhurst and Johnston 2010). Fishing communities are often located in hard to reach areas with poor access to health services and the high levels of mobility can make fisherfolks ability to access services including HIV testing and treatment services challenging (Seeley and Allison 2005).

Gendered power dynamics also play an important role in shaping vulnerability to HIV. In Malawian fishing communities (like in many other fishing communities in Africa), activities are often highly gendered with men undertaking the fishing and women negotiating access to fish through men. When fish catches are low and competition for fish is high, women engage in sex-for-fish exchanges with fishermen 
to ensure they have access to fish (MacPherson et al. 2012; Nagoli, Holvoet and Remme 2010). To date there have been no studies that have explored the role of MF in fishing communities in the global south. This gap needs to be interrogated to fully understand the opportunities and challenges that are posed by MF in this context.

The primary research objective of this study was to understand how microfinance shaped female fish traders' vulnerability to HIV in two fishing communities in Southern Malawi. 


\section{Methods}

In Malawi, $23 \%$ of land is covered with water (Government of Malawi 2007). Given the large bodies of fresh water covering Malawi's land, fish and the fisheries sector play an important role in providing employment, nutrition and income to Malawians. This study was based in two villages on the Southern-arm of Lake Malawi in Mangochi district, which is situated in the Southern Region of Malawi. Despite the wide body of water covering Malawi fishing activities are concentrated in the Mangochi district (Hara 2008) because the shallow water found in this area facilitates fish breeding (Darwall and Allison 2002). The Food and Agriculture Organisation of the UN (FAO) estimated that in 2003, 30\% of all livelihoods in Mangochi were in the fishing industry (the most recent data the authors could identify). Both of the villages were selected because of the large fish landing sites that are situated within the boundaries of the village. Many of the people living in the villages were heavily involved in fishing. However, the presence of large landing sites for boats meant that there was large inward and outward migration of people working within the fishing industry.

As noted above the prevalence rate in Malawi stands at $11.7 \%$. In keeping with prevalence trends in other Southern and Eastern African countries, young women are particularly vulnerable to HIV, with the prevalence among women aged 15-19 standing at $4 \%$ compared with less than $1 \%$ for men of the same age (National Statistical Office 2005a) 
The dominant form of fishing within the two study villages is $k a u n i^{2}$, which is focused on catching usipa a small cichlid fish. This type of small-scale fishing requires an engine boat, a crew of ten men, 3-4 dug-out canoes, lanterns and nets and takes place at night ${ }^{3}$. The fishing industry in Malawi, like many other countries is highly gendered with men undertaking the fishing and women buying, processing and selling fish at market. In this role female fish traders are highly mobile traveling from beaches across the district to access fish, drying them either in their homesteads or in the area they have purchased the fish then travelling to the market to see the fish (MacPherson et al. 2012). Female fish traders need to build and maintain capital for their fish trading business and spoke frequently of the challenges they face in maintaining their funds (MacPherson et al. 2012). The capital is primarily required to buy fish and pay for the transportation (both themselves to the different beaches and the fish to the markets once it had been processed). Even when women are able to access capital they often face with the challenge of securing access. Social norms within the villages prevent women from undertaking the fishing and therefore any access women had to fish had to be negotiated through men (MacPherson et al. 2012). Throughout the process of buying and selling fish female fish traders face a great deal of economic risk and uncertainty. One key way female fish traders mitigate is through develop sexual relationships with men that can help secure them access to fish (MacPherson et al. 2012). Given the transient nature of the fishing communities these are often transient relationships (particularly for divorced or widowed women).

\footnotetext{
${ }^{2}$ The term derives from the word kuunika that means to light or give light. The light refers to the lanterns that are used to attract.

${ }^{3}$ Ten men usually travel in the engine boat to parts of the lake where they believe there is a large presents of fish. The men then get into the dug-out canoes and use the lanterns to attract shoals of usipa fish to the surface and into the nets.
} 
The men physically undertaking the fishing are often young and socially marginalised. They also face a great deal of danger in their work. This includes the risk of drowning because fishing expeditions usually took place at night and men can and do fall into the water and be lost quickly especially when there are strong currents in the lake. The fishing expeditions often entail them spending long periods away from their home villages (sleeping on the beach or in cramped living conditions). Young fishermen are often paid in cash for their work and in poor rural villages this can provide the men with power and they can at times exploit this power by paying women to have sex with them (either for money or fish).

Fish catches in the villages are often very unpredictable during the rainy season and winter months, when there were strong winds, the fishing boats did not undertake fishing expeditions. During the periods of the month when there were a full moon, the fishing boats did not sail. This means the usipa fish trade is subject to temporal and seasonal variation, which can lead to very unpredictable supply. In this situation even very successful female fish traders faced competition with other female fish traders to access fish during periods of low fish catches. This is further exacerbated by the overall decline in fish stocks that Malawi has been experiencing particularly in the last two decades (Jamu et al. 2011).

The topic of this paper emerged out of a larger study exploring gender power relations in fishing communities in Southern Malawi and how these relations shaped women and men's vulnerability to HIV (MacPherson et al. 2012). Throughout the 
data collection, a wide range of participants (both men and women) discussed both the challenges and benefits of microfinance for women working in the fishing industry. Some participants linked it to providing women with economic independence from their male partners. But others discussed how microfinance created economic vulnerability and put women at risk of HIV. We therefore conducted a second period of data collection that explored women and men's experiences of using microfinance and how this shaped their lives including their vulnerability to HIV. We focused on female fish traders, as they were a group who had discussed the benefits and the challenges of accessing MF and using it within their businesses. The study used qualitative research methods including in-depth interviews, focus group discussion and structured observation ${ }^{4}$. Qualitative research methods were used because they allow data to be collected in participant's own words (Pope and Mays 1995). The interviews and focus groups were conducted with four research assistants (two men and two women). We used a purposive sampling frame with the aim of capturing the experiences of a range of groups (Lewis 2003). The groups included were older and younger women and men working in the fishing industry and borrowing from a range of microfinance organisations operating in the two villages.

This study ran from January 2011 until April 2012 and had two periods of data collection (January 2011-October 2011 and March-April 2012). In total we conducted 64 interviews and 18 focus groups with a range of participants working

\footnotetext{
${ }^{4}$ Ethical approval was obtained from the College of Medicine Research Ethics Committee, Malawi and Liverpool School of Tropical Medicine Research Ethics Committee. Further, permission to work in the district and villages was provided by the chiefs of both villages as well as district level representatives. Written informed consent was obtained from all individuals participating in the interviews and focus groups.
} 
inside and outside the fishing industry. For the second period of data collection we conducted in-depth interviews with 12 additional participants ( 8 women and 4 men). We conducted one or two interviews with each participant following up and holding a second interview with participants if we felt there were subsequent questions to explore further.

We purposefully sampled female and male individuals who had received a loan from a range of microfinance organisations. Table 1, provides an overview of the demographic information about the participants we interviewed in the second series of in-depth interviews. None, of the real names of participants have been used and instead we have assigned them a pseudonym. We used the framework approach to analysis the data. ${ }^{5}$

The timing of the fieldwork coincided with a period of time when the Malawian government was struggling to access foreign exchange. The limited access to foreign exchange meant fuel was very difficult to access and the cost of transportation and living costs became very expensive (Cammack 2012). This crisis was due in part to the increasingly autocratic style of the President Bingu wa Mutharika which led to the international donor community freezing large amounts of aid being delivered to

\footnotetext{
${ }^{5}$ To do this all interviews and focus groups were recorded, transcribed and translated into English by the research assistants. All transcripts were imported into Nvivo 9 and the programme was used to aid data analysis by coding against the framework. Data analysis began at the beginning of the data collection, continued throughout the data collection and was informed by the framework approach (Richie, Spencer and O'Connor 2003) The framework approach provides a systematic structure for analysis of qualitative data using both inductive and deductive approaches and entails five stages familiarisation, identifying a thematic framework, indexing the data, charting and mapping and interpreting (Pope, Ziebland and Mays 2000).
} 
the Malawian government. The Malawian economy was facing a severe crisis, however it is important to view these events in context. The Malawian economy is heavily reliant on international aid and commodities such as tobacco and tea, which often provide small economic returns, and prices can be unpredictable. The current President Joyce Banda is now facing corruption charges and the international community have again suspended aid (Mapondera 2014). There have also been severe food shortages for instance in 2002 when Malawi faced a famine with hundreds of people dying due to shortages of maize (the stable diet in Malawi) (Devereux 2002). These events suggest worrying trends in Malawian social and political context which also suggest that our period of data collection may sadly not be unique. In the interviews we asked participants to reflect on their use of microfinance loans over a longer period of time. None of the participants we interviewed were new to borrowing from MF organisations and we therefore do not believe that the results we present are only due to the wider crisis.

\section{Findings}

In the following sections we present the findings from this study around three themes; presence of microfinance in the village and the key groups they lent money to; the challenges and opportunities participants faced using microfinance; and how the unpredictability of the fishing industry, the short repayment timeframes, threat of property confiscation increased some female fish traders vulnerability to HIV.

In the two villages, participants identified eight organisations that were currently operating or had previously operated in the villages. Of these, participants most 
frequently discussed five organisations. Participants perceived the organisations to have slightly different procedures in terms of repayment, saving, deposit required to take the loan, loan size, interest rates and timing for distribution of the loan and these differences are outlined in Table 2 . To ensure anonymity of the participants we have not included the names of the MF organisations.

In all the discussions relating to microfinance, participants reported borrowing money in groups rather than as individuals. Participants discussed joining MF organizations in groups of between 10 and 20 and receiving the loan together on the same day. The group then assumed responsibility for repaying the whole loan rather than just their own portion of the money.

All the participants we interviewed who received loans were involved in fish trading. For the female participants, this was their primary mode of income generation although some would use the profits to buy tomatoes or beans and sell them in their local area. All the female participants discussed travelling to buy and sell fish. They often travelled to markets further than their home areas. Male participants also had other businesses that they developed in addition to fish trading. These businesses included carpentry, butchery and building and renting dwellings in the village.

Participants saw women as the preferred target group for microfinance organisations and they were the group most likely to have taken a loan. This reflects a number of studies which note women are the primary target for MF loans (Kulkarni 2011; Sengupta and Aubuchon 2008). The male participants we interviewed were all 
in the minority in their loan groups. One central reason that participants felt the MF organisations focused their activities on women was that they trusted women, but not men, to repay loans. Participants discussed how men could be untrustworthy with money for a number of reasons. Men, particularly, fishermen were not viewed as being serious about the loans and could use them for spending time at the bar drinking and having sex with sex workers. The highly mobile nature of many of the fishing activities meant men could be away from home for long periods of time, which could prevent them from repaying the loan. These views were also reflected in the broader community perceptions about men. Men, particularly young men, who travelled to fish were seen by many participants as being particularly untrustworthy with money. Women and men in the communities discussed how there was a culture of spending on drinking and women rather than on household needs.

Instead women discussed how they were the ones who were viewed as having to use their fish trading businesses to provide food for the family. Men who went out fishing often faced high levels of risk in their everyday activities. In other studies this has been seen as a reason why fishermen spend more money on sex workers when they travelled (Allison and Seeley 2004).

In the following Gracious discusses why men were not viewed as trustworthy to receive a loan:

P: $\quad$ Also, women are the ones mostly interested to do business. That's why they are also mostly involved in taking loans from organizations. Also, most of the 
organizations trust women more than men. They feel we men are crooks so they prefer women to men.

I: What do they exactly mean when they say men are crooks?

P: $\quad$ They say men are crooks because a man could take a loan today and suddenly start thinking about going to a bar to drink. So, as you go out to drink, you will realise you have spent half of the money. But women can't take money to a bar, no. [When they have received a loan], they will directly bring it home. IDI Gracious In the quote Gracious is discussing the justification that has been provided by microfinance organisations as to why their activities focused on women and not men.

To overcome this barrier, participants reported that men would use their wives to access the loan and then they took control of the loan for their business. In the following quote Gracious also discusses how some men use their wives as a way of overcoming this barrier of access:

Also, in other households, there are husbands who ask their wives to go and take a loan. They don't want the public to know that they are taking a loan, but they mutually agree in the house that the wife should go and take a loan. IDI Gracious

In this situation the male fish trader described a process that was undertaken with mutual consent. However, evidence from interviews also suggested that in some cases men could also pressure women into taking loans on their behalf and then leaving them with the responsibility of repaying. 


\section{Procedures for repaying the loans}

One aspect of the group formation that arose consistently during interviews was that groups required members to register their household property at the start of the loan cycle. Some of the participants discussed groups appointing an auditor to confirm that the property they had registered was in their possession and that it was worth what the participant had claimed it to be. Participants reported registering items such as livestock, kitchen utensils, bedding and furniture. The purpose of this property registration was that if the participants were unable to repay their loans then the group could confiscate the property and sell it to recover the money.

Another component of the group formation that participants discussed was the process of vouching for another member. As discussed earlier there is a high level of inward and outward migration to the villages. Unlike, in more stable rural populations there were often women (and men) wanting to join groups who were not known to the other members. If this scenario occurred, one group member would be asked to vouch for the new member. By vouching for the person they were agreeing to repay the loan, either with money or with the property they had registered. Usually a friend or relative vouched for new members.

The microfinance organisations did not seem to be involved in this process and instead it was the group's members who came up with their own practices for running the groups. However, it did appear that the loan officers were aware of property registrations because some of the participants reported providing the loan 
officer with written copies of these forms. Also given how consistently this practice came up it is likely that the loan officers who worked directly with the groups encouraged the practice. Participants also described at the beginning of the loan cycles being told that they could face arrest by the police if they did not repay their loans. Lamia Karim also discusses the practice of registering property at the commencement of the loan in her monograph documenting microfinance policy and practice in Bangladesh (Karim 2011). In her fieldwork she describes how she witnessed managers within the microfinance organisation compiling these lists and justifying their use by saying this is a bank and part of ensuring their bank received its money back. This suggests that the policy maybe part of broader MF practice.

\section{Experiences of taking and repaying a loan}

Participants provided complex narratives around their experiences of taking loans. Some participants found the experience positive but others found it very challenging. While none of the participants reported overwhelmingly positive experiences with microfinance, there were a number of participants who felt their lives had been improved by taking the loans. Examples included the loans allowing them to grow their businesses and improve the economic position of their households, including allowing them to pay for their children's school fees, buy clothes and food and in some cases build houses. For this reason participants often expressed gratitude at being able to access loans. In the quote below Rachel discusses how MF loans have helped her: 
Borrowing money has helped me. As I don't have a mother or a husband, the money from the organization is what is helping me. It is serving as my mother, father and husband. It assists me in everything I do. IDI, Rachel

Rachel discusses using microfinance loans in very positive terms. We have included it because it is illustrative of the high esteem some (although not all) participants held microfinance organisations and the personal connections they felt they had with the organisations. The quote also reflects that some female participants felt that microfinance provided economic support when this was absent in their lives. Rachel also went on to discuss how access to loans provided her with financial freedom from male sexual partners and stopped her from engaging in what she termed "promiscuous behaviour" as a means of accessing money. The positive accounts some female fish traders provided of the MF have been found in other settings. Bauchet and colleagues (2011) argue that MF can sometimes help loan recipients. However this is dependent on whether the client is able to actually make a profit from the loan (Bauchet et al. 2011). A final way that women felt they gained from microfinance was the group aspect of the loans. Some (again not all) of the participants reported gaining solidarity from being part of the groups. Mary felt that borrowing as a group enabled women to learn good business practices from the other group members.

While participants did speak positively about having access to microfinance loans, there were consistent testimonies from female fish traders that the loans increased economic vulnerability. This economic vulnerability was shaped by both the 
administration of the loans and the unpredictable nature of the fishing industry. Women faced hierarchies of access where wealthier and socially better-connected female fish traders had more secure access to fish. Women who were poor or had fewer social connections found access harder. Processing fish could be challenging particularly during the rainy season, when fish could rot on the drying benches. Traders also faced challenges with realising profit at the market. Hence in this context microfinance was able to temporarily provide women and men with better access to business capital but it did not change the broader structures and gendered inequalities that existed within the fishing industry.

Further, microfinance could at times make fish trader's livelihood strategies more stressful and difficult. The "grace period", the time between MF organisations providing participants with a loan and the participant having to repay the loan, was very short. For female fish traders negotiating access to fish, processing it and then selling it were all time consuming activities. Each point in this process could be time consuming and fraught with potential challenges. The tight deadlines and the looming fear of property confiscation meant that the microfinance loans placed incredible pressure on fish traders to make a profit. Women also reported that when loans were given to a large number of people in the community on the same day or very close in time, this also increased the competition between fish traders. The increased competition, particularly between female fish traders who struggled to gain access could drive the price of fish higher. This inflation of prices could mean women struggled to make a profit particularly if they ended up paying more than 
they were able to realise at the market. The precarious nature of making profit in the fishing industry could be further exacerbated by the presence of microfinance loans.

In the following quote the challenges of selling fish at the market are described by this 28-year-old bar tender and boat crew member. He emphasises how he saw this affected female fish traders' ability to repay their loans:

It is true.. fish catches these days change from time to time. They could buy fish but they find the market full of fish when they get there. They also find the price lower than the price at which they bought the fish. When they come back to buy more fish, they find that the price has also gone up. With this, the loan cannot benefit you. Some of them end up having their property forfeited because you initially consent to give your property should you fail to repay the loan. Focus group discussion, bar tender/boat crew member, 25-30, Chewa, married, dropped out of school in Form 2

Lender A's very short repayment policies were the most often cited as creating challenges for participants. They required participants to start repaying the loan within two weeks after receiving it and this could create problems especially during periods of low fish catches. In the following quote a 54-year-old female fish trader described receiving a loan and being unable to repay it because there were low fish catches:

I once joined Lender A but what was happening was at the time I took the loan there was no catches throughout that time. My children were going to school they needed fees so I just used some of the money I took from Lender A. After some days you hear that Lender A personnel they need the money from us so I just decided to quit Lender 
A because I was having problems. IDI 50-55 year old female fish trader, Tonga, divorced, female fish trader and collects firewood, dropped out of school at Standard 2

This was not the only participant who discussed using the loan for household expenses such as school fees and food rather than developing their business. When fish catches were low, some fish traders would use the loan for immediate household expenses that they needed to pay and were then unable to use the loan for income generation activities, making it difficult to repay the loan. Some participants discussed how these short repayment periods made them feel that taking a loan was not helping them to improve their financial situation, or support their families and at times made them poorer (because of the high interest rates that the organisations charged). If the microfinance organisations were slow to distribute the loan then participants also struggled to access fish. In the quote below taken from a focus group with male fish traders highlights how some microfinance organisations would be unpredictable.

Sometimes you plan to get a loan during a period of high fish catches but they [the microfinance organization] release very late. They release the loan when the season has passed. You feel happy just because you have received the loan but you can't use it for business that time. After three weeks of getting the loan, you are expected to start repaying the loan, but there is no fish to buy. It becomes painful. FGD, boat crew member/fish trader, 35-40 male, Tumbuka, married, dropped out in Standard 6 
As it can be seen in the quote above in the fishing industry fish traders faced tight windows of opportunity, when using a loan would enable them to improve their economic position. However, it was not always possible for fish traders to predict when this would occur and if MF were slow to distribute and quick to enforce repayment, fish traders would struggle to repay. When participants were struggling to repay the loan, which in the case of our study was nearly all the participants, they discussed various coping strategies to find money. These included using business capital that they had saved in addition to the loan, using savings they had built up with the microfinance organisation, borrowing from relatives, spouses and friends, borrowing from money lenders, selling their household goods or livestock and engaging in transactional sex.

\section{Stress and anxiety of meeting repayments}

Most of the participants who we interviewed discussed feeling stress and anxiety when they were trying to repay their loans. This worry was felt regardless of whether the participant had been able to repay their loan or not. Rachel in the quote above described microfinance organisations as being a replacement for her husband and family members also discussed the stress and worry that repaying the loan can cause.

I did the business frequently trying to make money because you don't sleep if you borrow somebody's money. You always think about returning it... I managed because I am afraid... When a repayment day becomes due, or I should say when a repayment day is a week away, you can start looking for the money until you have enough to repay IDI, Rachel 
Maureen who had taken a total of five loans from Lender $A$ articulated the consequences of this worry for the loan recipient:

I: What do you think are the challenges associated with taking a loan?

P: $\quad$ You meet many, so many challenges that you end up hanging yourself because of having so many worries about how to repay a loan. You don't have any relatives to turn to and you start wondering where you are going to find the money to pay back the loan. IDI, Maureen

Maureen cited a very extreme reaction to dealing with the challenges of taking a loan and we did not find any participants discussing anyone who had actually killed themselves because they had been unable to repay the loan. Yet, this was not the only female participant who discussed suicide and highlights how worried participants could feel about repaying their loans. There have been reports in the international media of suicides happening in other contexts in the global south because loan recipients could not repay their loans. One example of this is a spate of suicides that were reported in 2011, in the South Eastern Indian state of Andhra Pradesh. This is the same state we discussed in the introduction where the media reports came at the same time that the MF industry was facing serious crisis (Bateman and Chang 2012). The suicides of young women were seen as directly due to their inability to repay their mounting microfinance debts (Morris 2011).

The stress and anxiety that participants felt about repaying their loans was directly related to the consequences they would face if they were unable to meet their repayments. Confiscation of property, including their houses, was what participants 
most feared. The group nature of the borrowing created extra pressure for participants to repay. For groups to gain access to further loans (often of a higher value) all their members had to repay and if the group failed to repay then the members who had paid back would not be able to access another loan. It was also the groups and not the microfinance organisations that were responsible for collecting money when repayments were due. If a group member was unable to repay the loan then other members of the group would often have to provide the shortfall.

Groups were often made up of neighbours, friends and sometimes relatives and the public aspect of failing to repay could be very humiliating for the loan recipients. Groups could also make decisions on whether to help a participant with their repayments on the basis of how the group viewed the participant's behaviour. If the participant was not deemed to be behaving correctly then the groups might not help them with the outstanding repayments. This behaviour was related to how they were seen to be using the money in their homes or in their businesses. How these dynamics played out were very dependent on who was in the groups themselves and how they as a group viewed a participant's behaviour. The power to confiscate property gave the groups power over all its members, yet, it tended to be the poorest and least well socially connected who had their property confiscated. This was because they were the ones who were least able to find extra money if they were struggling with repayment. 
In the following quote, Brenda discusses how some groups could be very aggressive in pursuing participants who were struggling to make their repayments. While, this was a theme that came up across the interviews and focus groups, we included this quote because she was particularly eloquent at discussing this.

I feel there is always a risk because if someone doesn't have any money to pay the loan back, the kind of punishment they give him/her is too much. Because if the group has a meeting today on Wednesday, and you don't have any money to pay back, you start moving around the community trying to see if you can borrow money from someone. If you don't find the money and when you turn up at the meeting, you are not really respected. Many say "We are coming to your house". There is a Lender A group which I usually see gathering under that tree over there. They really show no respect for one another because they might go to somebody's house may be around 6 am and remain there until 10am. They are doing that to you even when you don't have any means of raising the money on that particular day. You may have tried to borrow from people but failed, but they insist that they get money from you so that they can bank it. So, even though people have not done it before, some of them run away from their houses escaping to another place leaving their children behind. They run away because of a challenge like this one which they might have encountered at that particular time. IDI, Brenda

These negative experiences of groups harassing each other are also reflected in Marr $(2002,2003,2006)$ studies on the effects of group lending in rural communities (Marr 2002; Marr 2003; Marr 2006). In her research she found that the joint-liability incentive devices produced significant changes in social interactions within groups 
which "damaged social cohesion and created negative effects on well-being and group stability" (Marr 2012)

In an interview with Brenda we explored further the process of property confiscation. She said that property confiscation was only done as a final recourse if the participant had been struggling to repay the loan throughout the loan cycle. She described this as occurring at 'injury time' when members of the group had tried to help with all other options and the time had run out for repayment of the whole loan.

Other participants also discussed property confiscation happening at the end of the repayment period rather than something that happened throughout the loan cycle. Gift, who reported not having challenges repaying his loan, described the process of property confiscation by the group. We have included this quote as it provides some insight into how group members who confiscate property come to this decision. This was one of the few incidents in which a participant narrated their role in confiscating other group members' property.

Well, if I had no money... we encourage every group member to save money with the organization so that if you have problems, the loan officer can write a letter signed by the Chairman and Secretary of the group and send it to the headquarters. At the headquarters, they can then transfer that person's savings to Lender A for the required repayment. If the savings of the person are not enough to meet the repayment, then every group member has to contribute so that the amount being owed to the organization is raised. Or else, we the group members should go to that 
person's house to take away and sell the property which they registered and declared to the group that could be sold out if they had problems paying back their loan. Not grabbing the property by force and without their consent. When they show the group the property, we ask them, "Are you willingly surrendering the property from the bottom of your heart? Maybe you have other means of raising the money?" Then they tell you saying, "No, I have tried several means of raising the money but I am not finding it. I am willingly releasing this property." That's when we now look for someone to buy the property. If any of the group members wants to buy it, they buy it. We then use the money for meeting the repayment so that we don't owe the organization any money, IDI Gift

In this discussion, Gift emphasises that the person who is having their property confiscated is giving the group their consent, perhaps suggesting that he is not altogether comfortable with this practice. In this description Gift is part of the group who is doing the confiscating and participants who had their property confiscated described how stressful, publically humiliating and economically ruinous it could be. Gift also discussed how other members could buy the confiscated property. In other interviews participants discussed how confiscated property might be sold cheaply to ensure the money was found quickly. This suggests that group members could actually have an economic incentive to confiscate the property of other members.

One challenge that came up in a number of interviews in relation to property confiscation was participants who had their property confiscated because they had vouched for another group member. In this scenario the participants had been able 
to repay their own loans but had been unable to repay the loan of the participant they had vouched for. In this following quote Irene discusses this scenario. I: How much was the money that you failed to repay? P: I had this property grabbed not because I had failed to repay my loan, but rather because of bearing witness for someone. I bore witness for someone who I had trusted but later ran away and escaped to the northern region. When the person had gone to the northern region, the property which was confiscated was mine, because the person was not reliably settled. She had no house. IDI Irene

In this situation the person who had given their trust to a relative or friend was economically penalised and by leaving the village and moving to the north there was no other way for the loan to be recovered by the group. When participants discussed having their property confiscated these were items such as bedding, cooking utensils, clothes and livestock. In the household women were responsible for providing food and having cooking utensils confiscated affected them more than their husbands.

\section{Microfinance, transactional sex and HIV risk}

Throughout the data collection participants reported microfinance as a reason why some women were vulnerable to HIV. In the study villages, some female fish traders used transactional sex as a way to access fish or generate capital for their businesses. Female fish traders' engagement in transactional sexual exchanges was often shaped by the unpredictability of the supply of fish at the lake and the demand for fish at the market. Female fish traders who were poorer or less well socially 
connected could struggle to access fish and lacked economic resources to cushion their income generation activities if they make a loss either during the processing or the selling of the fish. This situation, particularly when loans were given with very short repayment periods, increased the pressure for women to access fish quickly and to sell fish at a profit at the market. Given that both of these were areas of risk for female fish traders, taking loans could increase the chances of female fish traders engaging in transactional sex. The threat of property confiscation which was both publically humiliating and placed women in a worse economic position increased the pressure for women to make money and repay the loan. In the study villages income generation was almost completely dependent on fish catches and there were very few alternative livelihood strategies available for women, generating money outside the fish trade was not an option.

Both women and men discussed how some poor and less well connected female fish traders' engaged in transactional sex as a consequence of taking a loan. When it was discussed it was often seen as a last resort particularly when a repayment was due. In the following quote Alinafe discusses how this pressure to repay a loan could force women into engaging in transactional sex:

Agreement is a painful thing. If you promise to pay back K17,500 [£70] by the $30^{\text {th }}$ of a month, you must to do so no matter what. But you will find that you have been to the market three times and made losses on all the trips, and the repayment date may only be a few days away. There you decide to do something unacceptable which cannot help your life. You can put yourself at a certain risk. You will decide to do that so that perhaps you can raise $K 17,500$ [£70]...You can have sex with any man when 
you actually don't want it. You can sleep with him thinking that perhaps he can give you K2000 [£8]. You think that if he can give K2000 [£8], and if you could add it with the $K 2500$ [f10]... that maybe left in the house. You take the loan so that you can manage to feed your family, while you are actually selling your life because of taking a loan. IDI, Alinafe

Alinafe's quote highlights how women were driven to engage in transactional sex because of the pressure to repay their microfinance loan. In the quote the pressure that is created by the unpredictability of the fishing industry also comes across with Alinafe describing the continual trips to the market and the inability to sell the fish. Then the feeling of having to do something that they not want to do but instead have to do to ensure the loan is repaid.

The connection between MF and HIV risk also came up in other focus group discussions and in-depth interviews. In the quote below a female participant in a focus group discussion discusses the link. What is also clearly articulated is the relationship between taking a loan, engaging in transactional sex and acquiring HIV: I: what are the problems that arise due to the provision of the loans which require a repayment of 2 weeks?

R3: What happens is that I went to buy the fish at the Lake and it will take 4 days for me to dry the fish and then I take the fish to the market where the 2 weeks may elapse while at the market due to problems selling the fish. If you are under pressure to pay the loan you can end up having sex for money and coming back home with the disease. That is why we do not want the loan of 2 weeks but it should be at least 2 
months. FGD, female fish trader, 30-34, tumbuka, widow, left school at primary standard 8

In the quote below another female fish trader makes a direct link between MF loans and HIV risk:

When she sees that she has a loan to pay back, she offers to sell her body in order to raise money to pay back to the group, when she actually doesn't know about the health status of the man like whether he is infected or not. If the man is infected, it means she is going to contract the infection IDI Female fish trader, 30-34, Tonga, married, dropped out of school in primary standard 5.

In all three of these quotes the emphasis by the participants is placed on the pressure that repaying the microfinance loan in a very short period of time can place on female fish traders who are struggling to make a profit.

\section{Discussion and Conclusion}

We found a complex picture regarding female fish trader's experiences of using microfinance loans in the fishing industry. At times microfinance provided female fish traders with much needed business capital and access to social networks that allowed them to learn more about successful strategies for the fish trade. The access to business capital also allowed fish trader's economic independence from male sexual partners. Some women reported using the profits they generated from the loans within the household on both food and school fees for children. 
However, the fishing industry was highly unpredictable and female fish traders faced multiple uncertainties when trying to make a profit trading fish. Buying, processing and selling fish were all time consuming and female fish traders with poor social connections and few economic assets were in economically vulnerable positions. This was coupled with the highly gendered environment that meant women had to negotiate access to fish through men. Using microfinance loans particularly those with short grace periods and a threat of property confiscation placed further pressure on female fish traders to make a profit. If they made a loss the consequences were more acutely felt because fish traders had to continue to repay the loan with interest. When women had taken loans and were unable to repay them, engaging in transactional sex was one way of overcoming their need to find money to pay their loans. In a context of high HIV prevalence rates, such as fishing communities, microfinance loans could at times leave female fish traders vulnerable to HIV.

As noted in the introduction there has been important academic critiques of the way microfinance operates in the field and a number of authors have argued that microfinance can be disempowering for its female loan recipients (Goetz and Gupta 1996; Karim 2011; Rahman 1999). What the testimonies of the participants interviewed highlights is that being given a microfinance loan does not automatically lead to a successful business and alleviation of poverty for those provided with the loan. All the female fish traders discussed the challenges they faced in repaying the loan even the ones who considered microfinance to be helping their businesses. It therefore challenges the accepted orthodoxy that there is an automatic relationship 
between the provision of a MF loan and empowerment for women. Critics argue that one of the key reasons for the negative outcomes is the way microfinance organisations view success in their programmes. Principally success in MF organisations is measured by loan recovery rates rather than in more holistic measures of impact within the household or to participants' lives. In our study some participants reported intense pressure from fellow loan group members. The registering of property by the loan group at the beginning of the loan cycle is likely to be a reflection of the importance that the microfinance organisation placed on recovering their loans. The confiscation and selling of property was both publically humiliating and economically ruinous and lends weight to the argument that microfinance can be disempowering to its borrowers. In her monograph, Karim (2011) describes harrowing cases of loan recipients in Bangladesh having their homes dismantled and the pieces being sold bit by bit to repay their outstanding debt (Karim 2011: 117-123). This scenario was reflected in the experiences of the female fish traders taking loans in our study and perhaps speaks to a worrying systematic policy across MF organisations to recover their debts.

The group lending process has also attracted criticism, particularly the Grameen Bank's model where groups are responsible for repaying the whole loan rather than just their own proportion (Visvanthan and Yoder 2011). The concern with group lending is that MF organisations use group members as social collateral and exert undue pressure on borrowers to make repayments (Visvanthan and Yoder 2011: 53). This pressure can result in women borrowing money from money lenders and using subsequent loans to repay old debts creating a spiral of indebtedness that women 
struggle to break (ibid). We found this reflected in our research with some participants reporting intense pressure from each other to repay the loan. Participants also described how loan officers would only become involved after participants had tried hard to pressure their fellow loan recipients to repay. The only way participants could default on loans was to leave the village. However, this meant that other participants who had vouched for the member had to clear that group member's debt. This created heavy economic penalties for other group members and tense relationships in loan groups. When participants vouch for other members it is that participant not the microfinance who experiences a loss if the participant defaults on the loan. If MF organisations are measuring success on the grounds of loan repayments these dynamics may mask the true success (or lack of it) of programmes.

In the fishing industry female fish traders required access to business capital to perform their business. In our study all the women we interviewed discussed how they did retain control of their own loans and used the loan for their businesses. However, there were also examples of participants discussing men asking their wives to take loans for them. This reflects the findings in Mayoux's (1999) work on microfinance in a diverse range of African countries including Southern and West Africa. She found that the gender relations in the countries she worked in meant that women often retained control over their loans. This was in contrast to the findings in South Asia where academic studies have reported male relatives taking control of loans (Goetz and Gupta 1996). We also found that if women were able to make a profit from the loan they also retained control over the money realised from 
the loan. The loans therefore provided some women with an opportunity to gain financial independence from their partners. Providing some weight to the argument that microfinance could be empowering to the women who were included in programmes.

However, while some female fish traders in our study were successful in using their loans to make a profit they also continued to work in a highly gendered environment. The ability of female fish traders to access microfinance loans did not fundamentally alter these power relations. This provides further support for Cornwall and Edwards (2010) argument that empowering women is complex and requires more than a single intervention to achieve. It also speaks to the debates about structural interventions that prevent HIV through altering the broader structural factors that place women and men at an increased risk of HIV (Auerbach et al. 2009). As we noted in the introduction microfinance has previously been identified as a potential structural intervention. However, these finding suggest that MF is unlikely to significantly influence broader gendered power relations and therefore prevent HIV.

Finally, for women making money in the fishing industry was precarious. Female fish traders required access to money and social connections. For women without these social connections transactional sex was a way of developing and improving access to money and fish. This form of transactional sex is called sex for fish exchanges and has been reported in other fishing communities in Africa (Béné and Merten 2008; Merten and Haller 2007). We did not find any literature that explored microfinance 
in fishing communities. However, in the international literature transactional sex has previously been identified as a risk factor for HIV particularly in Southern and Eastern Africa where prevalence rates are high (Côté et al. 2004; Dunkle et al. 2004a; Dunkle et al. 2004b; Jewkes et al. 2012; Norris, Kitali and Worby 2009). This is because when relationships are formed on the basis of material benefit women often have less power to negotiate safer sexual practices (Jewkes et al. 2012). The intense pressure that microfinance placed on female fish traders drove some poorer and less well-connected women to engage in transactional sex in an environment with high HIV prevalence rate increasing their vulnerability to HIV. For public health programmes that aim to prevent HIV these findings provide a cautionary lesson.

The findings also provide weight to Kabeer (2005) and Matin and Hulme (2003) argument that for microfinance to be successful the product needs to be tailored to the needs and interests of the recipients. If microfinance is to be used in fishing communities it requires serious modification to reflect the realities of the women and men using it. Oya (2012) drawing on a range of work looking at the impact of MF in rural communities suggests microfinance could be re-ordinated and used for structural interventions that alter these structural constraints (Oya 2012). One example of this could be to use credit to support larger and more viable farms in rural communities that are "currently starved of appropriate longer-term as well as seasonal production credit" (Oya 2012: 554).

Female fish traders feared their property being confiscated. Stopping the confiscation of the property by groups would ease pressure on female fish traders. 
Furthermore, allowing fish traders more flexibility with their repayment schedules, reflecting the unpredictable nature of the fishing industry, would improve women's ability to use their loans. In relation to public health interventions that wish to prevent HIV, in high-risk settings in Southern Africa where HIV prevalence is high microfinance is unlikely to be a tool that will be successful in preventing HIV vulnerability.

A key limitation of the study was not including representatives from the MF organisations that the participants discussed. This study was undertaken at the end of the larger study and we did not have time to seek ethical approval to conduct interviews with MF organisations. However, while this is a key limitation much of the themes that were discussed by the participants were also discussed in the international literature and provide weight to the data.

In conclusion, we found a complex picture of the role microfinance played in fishing communities in Southern Malawi. Across the dataset microfinance was seen as increasing female fish traders economic vulnerability and risk of HIV. Urgent modification of MF products is required to protect highly vulnerable women. Finally in fishing communities, microfinance should not be used as a tool to prevent HIV. 
References

Allison, E. H., and J. A. Seeley. 2004. "HIV and AIDS among fisherfolk: a threat to 'responsible fisheries'?" Fish and Fisheries 5:215-34.

Auerbach, J.D. , J.O. Parkhurst, Keller K.E., C. Caceres, and K.E. Keller. 2009. "Addressing Social Drivers of HIV/AIDS: Some Conceptual, Methodological, and Evidentiary Considerations." in aids 2031 Working Paper Massachusetts, US: aids2031.

Banerjee, Abhijit, Esther Duflo, Rachel Glennerster, and Cynthia Kinnan. 2013. "The miracle of microfinance? Evidence from a randomized evaluation." MIT Department of Economics Working Paper 13-09.

Bateman, Milford, and Ha-Joon Chang. 2012. "Microfinance and the illusion of development: from hubris to nemesis in thirty years." World Economic Review 1(1):13-36.

Bauchet, Jonathan, Cristobal Marshall, Laura Starita, Jeanette Thomas, and Anna Yalouris. 2011. "Latest findings from randomized evaluations of microfinance." in Access to Finance Forum.

Béné, C., and S. Merten. 2008. "Women and Fish-for-Sex: Transactional Sex, HIV/AIDS and Gender in African Fisheries." World Development 36(5):875-99.

Cammack, Diana. 2012. "Malawi in crisis, 2011-12." Review of African Political Economy 39(132):375-88.

Cornwall, A., and J. Edwards. 2010. "Introduction: Negotiating Empowerment." IDS Bulletin 41(2):1-9.

Côté, A.M., F. Sobela, A. Dzokoto, K. Nzambi, C. Asamoah-Adu, A.C. Labbé, B. Mâsse, J. Mensah, E. Frost, and J. Pépin. 2004. "Transactional sex is the driving force in the dynamics of HIV in Accra, Ghana." AIDS 18(6):917-25.

Darwall, W.R.T., and E. H. Allison. 2002. "Monitoring, assessing, and managing fissh stocks in Lake Malawi/Nyassa: Current approaches and future possibilities." Aquatic Ecosystem Health \& Management 5(3):293-305.

Deane, KD, JO Parkhurst, and D Johnston. 2010. "Linking migration mobility and HIV." Tropical Medicine and International Health 15(12):1458-63.

Devereux, Stephen. 2002. "The Malawi Famine of 2002." IDS Bulletin 33(4):70-78.

Dunbar, M. S., M. C. Maternowska, M. S. Kang, S. M. Laver, I. Mudekunye-Mahaka, and N. S. Padian. 2010. "Findings from SHAZ!: a feasibility study of a microcredit and life-skills HIV prevention intervention to reduce risk among adolescent female orphans in Zimbabwe." J Prev Interv Community 38(2):147-61.

Dunkle, K.L., R. Jewkes, H.C. Brown, G.E. Gray, J.A. McIntryre, and S.D. Harlow. 2004a. "Gender-based violence, relationship power, and risk of HIV infection in women attending antenatal clinics in South Africa." Lancet 363:1415-21.

Dunkle, K.L., R.K. Jewkes, H.C. Brown, G.E. Gray, J.A. McIntryre, and S.D. Harlow. 2004b. "Transactional sex among women in Soweto, South Africa: prevalence, risk factors and association with HIV infection." Soc Sci Med 59(8):1581-92.

Dworkin, S.L., and K.M. Blankenship. 2009. "Microfinance and HIV/AIDS Prevention: Assessing its Promise and Limitations." AIDS Behav 13:462-69. 
Epstein, H. 2007. The invisible cure: Africa, the West and the fight against AIDS. London: Penguin.

Goetz, A. M , and S Gupta, R. 1996. "Who Takes the Credit? Gender, Power and Control over Loan Use in Rural Credit Programmes in Bangladesh." World Development 24(1):45-63.

Government of Malawi. 2006. "Behavioural Surveillance Survey Report." Lilongwe, Malawi: Office of the President and Cabinet.

-. 2007. "The Fish Sector and Its Importance in Malawi." ESA Meeting on Trade and Sustainable Approaches to Fisheries Negotiations under WTO/EPA, The Commonwealth Secretariat, Port Louis, Mauritius, 2-4 May 2007.

-. 2009. "National HIV Prevention Strategy and Action Plan." Lilongwe, Malawi: Office of the President and Cabinet.

Hara, M. 2008. "Dilemmas of democratic decentralisation in Mangochi District, Malawi: Interest and Mistrust in Fisheries Management "Conservation and Society 6(1):74-86.

Holvoet, Nathalie. 2005. "The Impact of Microfinance on Decision-Making Agency: Evidence from South India." Development and Change 36(1):75-102.

Jamu, Daniel, Moses Banda, Friday Njaya, and Robert E. Hecky. 2011. "Challenges to sustainable management of the lakes of Malawi." Journal of Great Lakes Research 37, Supplement 1(0):3-14.

Jewkes, R., R. Morrell, Y. Sikweyiya, K. Dunkle, and L. Penn-Kekana. 2012. "Transactional relationships and sex with a woman in prostitution: prevalence and patterns in a representative sample of South African men." BMC Public Health 12:325.

Johnson, S. 2005. "Gender Relations, Empowerment and Microcredit: Moving on from a Lost Decade." The European Journal of Development Research 17(2):224-48.

Kabeer, N. 2001. "Conflicts Over Credit: Re-Evaluating the Empowerment Potential of Loans to Women in Rural Bangladesh." World Development 29(1):63-84.

Kabeer, N. 2005. "Is Microfinance a 'Magic Bullet' for Women's Empowerment? Analysis of Findings from South Asia." Economic and Political Weekly.

Kalpana, K. 2011. "Negotiating multiple patriarchies: women and microfinance in South India " in The Women, Gender and Development Reader, edited by N. Visvanthan, L. Duggan, N. Wiegersma, and L. Nisonoff. New York: Zed Books.

Karim, Lamia. 2011. Microfinance and its discontents: Women in debt in Bangladesh: $\mathrm{U}$ of Minnesota Press.

Karlan, Dean, and Martin Valdivia. 2011. "Teaching entrepreneurship: Impact of business training on microfinance clients and institutions." Review of Economics and Statistics 93(2):510-27.

Kim, J. C., and C. H. Watts. 2005. "Gaining a foothold: tackling poverty, gender inequality, and HIV in Africa." BMJ 331(7519):769-72.

Kissling, E., E.H. Allison, J.A. Seeley, S. Russell, M. Bachmann, S.D. Musgrave, and S. Heck. 2005. "Fisherfolk are among groups most at risk of HIV cross-country analysis of prevalence and numbers infected." AIDS 19(17):1939-46.

Korth, M., R. Stewart, C. Van Rooyen, and T. De Wet. 2012. "Microfinance: Development Intervention or Just Another Bank?" Journal of Agrarian Change 12(4):575-86. 
Kulkarni, V.S. 2011. "Women's empowerment and microfinance: An Asian Perspective." in Occasional Paper Rome, Italy: International Fund for Agricultural Development.

Kwena, Zachary A., Carol S. Camlin, Chris A. Shisanya, Isaac Mwanzo, and Elizabeth A. Bukusi. 2013. "Short-Term Mobility and the Risk of HIV Infection among Married Couples in the Fishing Communities along Lake Victoria, Kenya." PLoS One 8(1):e54523.

Lewis, J. 2003. "Design issues." in A guide for social science students and researchers, edited by J. Richie and J. Lewis. Thousand Oaks, CA: Sage.

MacPherson, E. E., J. Sadalaki, M. Njoloma, V. Nyongopa, L. Nkhwazi, V. Mwapasa, D. G. Lalloo, N. Desmond, J. Seeley, and S. Theobald. 2012. "Transactional sex and HIV: understanding the gendered structural drivers of HIV in fishing communities in Southern Malawi." J Int AIDS Soc 15 Suppl 1:1-9.

Mapondera, Godfrey. 2014. "Malawi prepares for $\$ 100 m$ 'cashgate' corruption trial." in The Guardian. Manchester.

Marr, Ana. 2002. "Studying group dynamics: an alternative analytical framework for the study of microfinance impacts on poverty reduction." Journal of International Development 14(4):511-34.

-. 2003. "A challenge to the orthodoxy concerning microfinance and poverty reduction." Journal of Microfinance/ESR Review 5(2):7-42.

-. 2006. "The limitations of group-based microfinance and ways to overcome them." Small Enterprise Development 17(3):28-40.

-. 2012. "Effectiveness of Rural Microfinance: What We Know and What We Need to Know." Journal of Agrarian Change 12(4):555-63.

Matin, Imran, and David Hulme. 2003. "Programs for the Poorest: Learning from the IGVGD Program in Bangladesh." World Development 31(3):647-65.

Mayoux, Linda. 1999. "Questioning virtuous spirals: micro-finance and women's empowerment in Africa." Journal of International Development 11(7):957-84.

Mersland, Roy, and R Øystein Strøm. 2010. "Microfinance mission drift?" World Development 38(1):28-36.

Merten, S., and T. Haller. 2007. "Culture, changing livelihoods, and HIV/AIDS discourse: reframing the institutionalization of fish-for-sex exchange in the Zambian Kafue Flats." Cult Health Sex 9(1):69-83.

Morduch, J. 2000. "The Microfinance Schism." World Development 28(4):617-29.

Morris, Madeleine. 2011. "Investigating India's microcredit crisis." BBC World Service.

Nagoli, J., K. Holvoet, and M. Remme. 2010. "HIV and AIDS vulnerability in fishing communities in Mangochi district, Malawi." African Journal of AIDS Research 9(1):71-80.

National Statistical Office. 2005a. "Malawi Demographic and Health Survey 2004." Calverton, Maryland.

Norris, A. H., A. J. Kitali, and E. Worby. 2009. "Alcohol and transactional sex: how risky is the mix?" Soc Sci Med 69(8):1167-76.

Oya, Carlos. 2012. "Introduction to a Symposium on Microfinance and Rural Development: Magic Bullet or Blank Bullet?" Journal of Agrarian Change 12(4):552-54 . 
Pankhurst, H. 2002. "Passing the Buck? Money Literacy and Alternatives to Credit and Savings Schemes." Gender \& Development 10(3):10-21.

Pope, C, and N Mays. 1995. "Reaching the parts other methods cannot reach: an introduction to qualitative methods in health and health services research " BMJ 311(6996):42-5.

Pope, C., S. Ziebland, and N. Mays. 2000. "Qualitative research in health care analysing qualitative data." BMJ 320:114-16.

Pronyk, Paul M., James R. Hargreaves, Julia C. Kim, Linda A. Morison, Godfrey Phetla, Charlotte Watts, Joanna Busza, and John D. H. Porter. 2006. "Effect of a structural intervention for the prevention of intimate-partner violence and HIV in rural South Africa: a cluster randomised trial." Lancet 368(9551):197383.

Rahman, Aminur. 1999. "Micro-credit initiatives for equitable and sustainable development: Who pays?" World Development 27(1):67-82.

Ritchie, J, L Spencer, and W O'Connor. 2003. "Carrying out qualitative analysis." Pp. 219-62 in Qualitative Research Practice: A guide for social science students and researchers, edited by J Richie and J Lewis. Thousand Oaks, CA: Sage.

Seeley, J. A., and E. H. Allison. 2005. "HIV/AIDS in fishing communities: challenges to delivering antiretroviral therapy to vulnerable groups." AIDS Care 17(6):68897.

Seeley, J., C. H. Watts, S. Kippax, S. Russell, L. Heise, and A. Whiteside. 2012. "Addressing the structural drivers of HIV: a luxury or necessity for programmes?" Journal of the International AIDS Society 15 Suppl 1:1-4.

Seeley, Janet, Grace Tumwekwase, and Heiner Grosskurth. 2009. "Fishing for a Living but Catching HIV: AIDS and Changing Patterns of the Organization of Work in Fisheries in Uganda." Anthropology of Work Review 30(2):66-76.

Sengupta, Rajdeep, and Craig P Aubuchon. 2008. "The microfinance revolution: An overview." REVIEW-FEDERAL RESERVE BANK OF SAINT LOUIS 90(1):9.

Tumwesigye, N. M., L. Atuyambe, R. K. Wanyenze, S. P. Kibira, Q. Li, F. WabwireMangen, and G. Wagner. 2012. "Alcohol consumption and risky sexual behaviour in the fishing communities: evidence from two fish landing sites on Lake Victoria in Uganda." BMC Public Health 12:1069.

van Rooyen, C., R. Stewart, and T. de Wet. 2012. "The Impact of Microfinance in SubSaharan Africa: A Systematic Review of the Evidence." World Development 40(11):2249-62.

Visvanthan, N., and K. Yoder. 2011. "Women and microcredit: a critical introduction." in The Women, Gender and Development Reader, edited by N. Visvanthan, L. Duggan, N. Wiegersma, and L. Nisonoff. New York: Zed Books. 
Table 1: Demographic information relating to microfinance IDIs

\begin{tabular}{|c|c|}
\hline Interview code & Demographic information \\
\hline M1 Rachel & $\begin{array}{l}\text { Female, } 30-35 \text {, Tumbuka, Anglican, } \\
\text { divorced from husband for second time, } \\
\text { fish trader, sold fish at far markets, } \\
\text { dropped out } \mathrm{S} 8 \text {, }\end{array}$ \\
\hline M2 Mary & $\begin{array}{l}\text { Female, 50-55, Tonga, CAP, widowed in } \\
2005 \text { (married twice), fish trader, sold } \\
\text { fish at far markets, dropped out of } \\
\text { school in S4 }\end{array}$ \\
\hline M3 Marvellous & $\begin{array}{l}\text { Female, } 30-35 \text {, Tonga, CAP, married for } \\
\text { a second time still with her husband a } \\
\text { fisherman, trades fish, sold fish at far } \\
\text { market, dropped out of school in } \mathrm{S7} \text {, }\end{array}$ \\
\hline M4 Maureen & $\begin{array}{l}\text { Female, } 36-40 \text {, Tonga, Holy Pentecostal } \\
\text { Church, widowed and then divorced, } \\
\text { trades fish, sells at far away markets; } \\
\text { dropped out of school in S8, }\end{array}$ \\
\hline M5 Annie & $\begin{array}{l}\text { Female, 30-35, Chewa, Anglican, } \\
\text { married, fish trader; sells fish at far } \\
\text { markets; usually accesses fish from her } \\
\text { husbands boat dropped out of school in } \\
\text { S6, }\end{array}$ \\
\hline M6 Irene & $\begin{array}{l}\text { Female, } 45-50 \text {, Tumbuka, divorced } \\
\text { female fish trader (second time), fish } \\
\text { trader at far markets dropped out of } \\
\text { school at S8, }\end{array}$ \\
\hline M7 Brenda & $\begin{array}{l}\text { Female, 30-35, Tonga, Anglican, married } \\
\text { but husband left for South Africa in } \\
\text { 2008, undertakes small-scale fish } \\
\text { trading; dropped out of school in S6 }\end{array}$ \\
\hline M8 Alinafe & $\begin{array}{l}\text { Female, } 40-45 \text {, Tonga married for a } \\
\text { second time, female fish trader, traded } \\
\text { larger fresh fish not smaller dried fish, } \\
\text { parents owned boats and fishing gear } \\
\text { and well connected, dropped out of } \\
\text { school in S8 }\end{array}$ \\
\hline M9 Gracious & $\begin{array}{l}\text { Male, 35-40, Tumbuka, African } \\
\text { International Church, married for a } \\
\text { second time, fishes and trades fish } \\
\text { using MF loan, dropped out of school in } \\
\text { Form } 3\end{array}$ \\
\hline M10 Richard & $\begin{array}{l}\text { Male, } 30-35 \text {, Tonga, married for second } \\
\text { time, fish trader who works with his }\end{array}$ \\
\hline
\end{tabular}




\begin{tabular}{|l|l|}
\hline & $\begin{array}{l}\text { wife; completed school and trained as } \\
\text { an engineer }\end{array}$ \\
\hline M11 Wickson & $\begin{array}{l}\text { Male, 25-30, Lomwe, CCAP, carpenter } \\
\text { and fish trader, married, left school in } \\
\text { secondary form 4 }\end{array}$ \\
\hline M12 Gift & $\begin{array}{l}\text { Male, 35-40, Tumbuka, male fish trader } \\
\text { (although also butcher and land lord), } \\
\text { married for a second time; completed } \\
\text { school }\end{array}$ \\
\hline
\end{tabular}


Table 2: Reported differences between microfinance organisations

\begin{tabular}{|c|c|}
\hline Organisation & Reported differences \\
\hline Lender $A$ & $\begin{array}{l}\text { Repayment within } 2 \text { weeks of loan disbursement; } \\
\text { Deposit required; } \\
\text { Progressively larger loan sizes; } \\
\text { Viewed to have high interest rates and less flexibility; } \\
\text { Savings kept within the organisation; } \\
\text { Provided loans to women and men (although majority women); } \\
\text { NGO }\end{array}$ \\
\hline Lender B & $\begin{array}{l}\text { Were seen to be more flexible with a } 3 \text { month lag between the } \\
\text { loan and the first repayment; } \\
\text { Perceived to have lower interest rates than Lender A; } \\
\text { Provided smaller loans; } \\
\text { Slower to distribute the money } \\
\text { Hard for participants to get subsequent loans quickly; } \\
\text { NGO }\end{array}$ \\
\hline Lender $\mathrm{C}$ & $\begin{array}{l}\text { Monthly repayments; } \\
\text { Seen as requiring a larger deposit; } \\
\text { Participants discussed losing this deposit when their groups } \\
\text { were unable to make the repayments; } \\
\text { Government owned and run }\end{array}$ \\
\hline Lender D & $\begin{array}{l}\text { Provides a grace period of approximately a month and a half } \\
\text { before repayments began; } \\
\text { No flexibility once repayments had begun } \\
\text { Allowed participants to gain larger loans once they had } \\
\text { successfully repaid } \\
\text { Provided loans to both male and female participants; } \\
\text { NGO }\end{array}$ \\
\hline Lender $\mathrm{E}$ & $\begin{array}{l}\text { Only lend to women; } \\
\text { Repayment due every two weeks; } \\
\text { Viewed as having higher interest rates; } \\
\text { NGO }\end{array}$ \\
\hline
\end{tabular}

